\title{
A systematic integrative review of parents experience and perception of sleep when they stay overnight in the hospital together with their sick children
}

Borghild Loyland, Charlotte Angelhoff, Gudrun Kristjansdottir and Hege Sjolie

The self-archived postprint version of this journal article is available at Linköping University Institutional Repository (DiVA):

http://urn.kb.se/resolve?urn=urn:nbn:se:liu:diva-163025

N.B.: When citing this work, cite the original publication.

Loyland, B., Angelhoff, C., Kristjansdottir, G., Sjolie, H., (2020), A systematic integrative review of parents experience and perception of sleep when they stay overnight in the hospital together with their sick children, Journal of Clinical Nursing. https://doi.org/10.1111/jocn.15134

Original publication available at:

https://doi.org/10.1111/jocn.15134

Copyright: Wiley (12 months)

http://eu.wiley.com/WileyCDA/ 
Title: A systematic integrative review of parents' experience and perception of sleep when they stay overnight in the hospital together with their sick children

Running title: Parents' sleep with hospitalized children

Borghild LØYLAND, Associate Professor PhD, RN ${ }^{1}$

Charlotte ANGELHOFF ${ }^{2,3} \mathrm{PhD}, \mathrm{RN}$

Gudrún KRISTJÁNSDÓTTIR Professor, DrPH/PhD, RN ${ }^{4,5}$

Hege SJØLIE Associate Professor, $\mathrm{PhD}^{1}$

Department of Nursing and health promotion, Faculty of Health Sciences,

OsloMet - Oslo Metropolitan University, Norway ${ }^{1}$

Department of Social and Welfare Studies, Division of Nursing Science, Linköping

University, Norrköping, Sweden ${ }^{2}$

Department of Pediatrics and Department of Clinical and Experimental Medicine, Linköping University, Linköping, Sweden ${ }^{3}$

University of Iceland, Faculty of Nursing, Reykjavík, Iceland ${ }^{4}$

Landspitali University Hospital, Hringur Children's Hospital, Reykjavik, Iceland ${ }^{5}$

Number of words: 5028

Conflict of interest: We have no conflicts of interest to declare

Corresponding author: Borghild Løyland, Oslo Metropolitan University, Department of Nursing and health promotion, Faculty of Health Sciences, e-mail address:

borglo@,oslomet.no

Phone $+47-67236143$ 


\section{Abstract}

Aims and objectives. To elucidate knowledge available on parents' experience and perception of sleep when they stay overnight in hospital together with their sick children.

Background: In Nordic countries, children are entitled to have at least one parent with them during hospitalization. Parents' sleep, when accommodated at the hospital during the child's admission, may be a challenge.

Design: A systematic literature search was conducted in EMBASE, MEDLINE, PsychINFO, period is restricted from January 1, 2007 to April 1, 2019. Studies included were those in which parents were accommodated in hospital with their child, 0-18 years of age, for at least one night. Original peer-reviewed scientific research papers conducting qualitative, quantitative or mixed designs were included. Systematic reviews were not included. This systematic integrative review was registered in PROSPERO and performed according to the PRISMA guidelines. All authors participated in study selection, data extraction, and quality assessment of the literature.

Results: Fifteen studies were included and they varied in terms of origin, aims, design, methods used, and sample size. Three overall main themes appeared: sleep quality, factors affecting sleep, and consequences of sleep loss. Combined psychological factors were found to affect parents' sleep, as well as isolated psychological factors, e.g., stress, anxiety, worries and difficult thoughts. Environmental and social factors were also identified, e.g., privacy, and caring for family.

Conclusion: Study of this subject is still in its exploratory phase. There is a need for the development of theory of substance in the clarification of the meaning of sleep among parents during difficult times such as children's hospitalization.

Relevance to Clinical Practice: Understanding risk factors associated with sleep and sleep deprivation in parents staying overnight in the hospital with their sick child is important, since lack of sleep may lead to serious stress-related outcomes for the parents. 


\section{Introduction}

In the Nordic countries, children have the right to have at least one of their parents with them during a hospital stay (Davies, 2010). Taking the parents into the hospitals during the child's admission has been encouraged both by family interest groups and by professionals over the last decades (Stremler, Wong, \& Parshuram, 2008). During the last 40 years, in the Nordic countries, but also in other western countries, practice has changed from parents being almost absent to the expectation that the parents be together with the child $24 / 7$ during the entire hospital stay (Strembler et.al., 2008, McLoone, Wakefield, Yoong, Cohn, 2013). The argument is primarily that having a parent together with the child will improve the child's experiences and their ability to cope during the hospitalization. Despite this change in practice, little research has been conducted surrounding consequences of parents staying overnight in these settings. There may be many good reasons for the change in practice, as children often have a range of fears and concerns when they are in the hospital (Coyne, 2006). These stressors include: separation from parents and family, unfamiliar environment, investigations and treatments, and loss of self-determination. However, having a child hospitalized is also stressful for parents and families (Commodari, 2010; Diffin, Spence, Naranian, Badawi, \& Johnston, 2016; Power \& Franck, 2008). Parents' sleep, when accommodated at the hospital during the child's admission, can be challenging and parents' disrupted sleep over a long time is experienced as a burden, is stressful, and reduces their quality of life (Doering \& Durfor, 2011). Further, the interruption of parental sleep during the nights over a long period affects and limits the parents' abilities to meet the children's needs and to maintain parental wellbeing (Institute of Medicine Committee on Sleep, 2006; Morris, Aeschbach, \& Scheer, 2012). Sleep deprivation and poor quality of sleep adds to the stress experienced by parents staying with a child at a hospital (McCann, 2008). Therefore, understanding risk factors associated with sleep and sleep deprivation in parents staying overnight in the hospital with their sick child is important. 
According to a recent study, insufficient sleep quality of parents at pediatric wards predicts negative mood, and the parents report being less alert, being less interested, having reduced concentration, and being more tired, dull, and passive in the hospital than at home after discharge (Angelhoff, Edell-Gustafsson, \& Morelius, 2017). In summary, while children are entitled to be accompanied by at least one parent during a hospital stay, the resulting lack of sleep experienced by the parent may lead to serious stress-related outcomes for that parent.

\section{Aims}

This systematic integrative review study was conducted to elucidate the knowledge available on parents' experience and perception of sleep, when they stay overnight in the hospital together with their sick children.

\section{Methods}

Design

This systematic integrative review was registered in PROSPERO (registration number: CRD42017079615) and performed according to the Preferred Reporting Items for Systematic review and Meta-Analysis guidelines (PRISMA, 2017), (see Supplementary File 1). Ethical approval is not required for this review.

\section{Search strategy}

In October 2017, an initial systematic literature search was conducted with the assistance of a research librarian. The selected databases were EMBASE, MEDLINE, Psych INFO (in OVID) and Cinahl. Language was restricted to English and Nordic (Norwegian, Swedish, Icelandic or Danish) languages, and the period restricted to January 1, 2007-September 30, 2017. Followup searches were made during the time period from October1, 2017 until April 1, 2019 (see Figure 2 Flow Chart). We searched for parent's experience and perception of sleep when they 
are accommodated with their sick children in the hospital. MESH terms used were related to "parents", "sleep", "hospitalized children" and "pediatric hospital". This gave a broad search covering the MESH terms exemplified in Figure 1, but also others related to the same words. Additionally, we searched through open field search related to the same terms.

\section{Inclusion and exclusion criteria}

Studies were included when parents were accommodated together with their child, 0-18 years old, at least one night in the hospital. Original peer-reviewed scientific research papers conducting qualitative, quantitative, or mixed designs were included, but not systematic reviews. Exclusion criteria was parents sleeping at home, papers with anonymous authors, and conference abstract.

\section{Quality assessment}

Articles meeting the inclusion criteria were scored according to Critical Appraisal Skills Program (CASP) for evaluating qualitative studies (CASP, 2014), and with a checklist for prevalence studies from the Norwegian Institute of public health (NPH) based on EBMH Notebook (NPH, 2017, Notebook, 1998). CASP was used for assessing qualitative studies in the selection, with a maximum score of ten. The checklist includes the following criteria: (i) was there a clear statement of the aims, (ii) is a qualitative methodology appropriate, (iii) was the research design appropriate to address the aims of the research, and (iv) was the recruitment strategy appropriate to the aims of the research. Further, (v) was the data collected in a way that addressed the research issue, (vi) has the relationship between researcher and participants been adequately considered, (vii) have ethical issues been taken into consideration, (viii) was the data analysis sufficiently rigorous, (ix) is there a clear statement of findings, and (x) how valuable is the research? The checklist for prevalence studies included twelve questions with the following criteria: (i) if the study is addressing a clearly focused issue, (ii) if a prevalence 
study was a suitable method to use and (iii) if the population were defined clearly. Further, (iv) if the recruitment strategy was appropriate and (v) if responders and non-responders differ, (vi) if the response rate is high enough, (vii) if the studies used valid and reliable measurements and (viii) if the data collection method and (ix) analyses were standardized. The last three criteria focused on the study results, and were not included in the present review. Criterion (x) asked what the results of this study were, and was without a possibility to answer a yes or no. Criterion (xi) dealt with the possibility of transferring the results to practice. The last criterion (xii) inquired if the results coincide with other studies.

\section{Data extraction}

All authors were reviewers and participated in study selection, data extraction and quality assessment of the literature. In the initial step, two reviewers independently screened the titles and abstracts of all articles, eliminating those that were not relevant to the aims of the review. In the next step, all four authors independently assessed the selected articles for further review, to determine whether they met the inclusion criteria. Further on, one reviewer extracted data using a data extraction form, while two others assured the quality by re-checking the form and articles. Discrepancies that the individual reviewers found among the data were discussed in the group until a consensus was reached. In Figure 2, a flow chart describes the selection of studies. The data extracted was authors, publication year, country in which the study was conducted, aim, design and methodology of the study, number of participants, where the parents stayed overnight, results, conclusion, need for further research, and limitations of the study.

\section{Results}

After removing duplicates, the database search returned 669 articles. Of these, only 15 articles were found to be in accordance with the inclusion criteria (Table 1). The articles varied in terms of origin, aim, design, method used, and sample size. As shown in Table 1, all the selected 
studies scored eight or higher on the two quality assessment scales. Of the included studies, five were conducted in Sweden, three in the United Kingdom, three in Canada, two studies were from Australia and one from South Korea and United States respectively. One article was published in 2008, two were published in 2011-2012 and the rest were published after 2013.

Aims

The aims of the included studies varied (Table 1). They aimed to capture the sleep quality and mood, and how parents perceived their own sleep during a night in a children's hospital (Angelhoff et al., 2017; McCann, 2008; Meltzer et al., 2012; Stickland et al., 2016). The included studies explored and documented parents' experiences of factors in the neonatal intensive care unit that made it easier, or more difficult, for them to stay with their extremely preterm infant (Blomqvist et al., 2017; Edéll-Gustafsson et al., 2015; Heinemann et al., 2013). Also included in the aims of the studies were: the documentation of physiological, psychological, and situational factors affecting fatigue among mothers (Kim et al., 2017). Other aims were: prevalence estimates of self-report sleep quantity and quality among parents accommodated on the pediatric oncology ward (McLoone et al., 2013), and descriptions and measurement of sleep quantity and sleep patterns (Nassery et al., 2018, Bevan et al., 2019). Additionally, factors affecting the sleep of parents with critically ill children (Stremler et al., 2014; R. Stremler et al., 2017) as well as strategies used to improve parents' sleep (Stremler et al., 2011). Finally, aims also included comparisons of sleep quality and quantity among the parents who were accommodated bedside at the hospital and those who slept at a Ronald McDonald House (Franck et al., 2014).

Definitions of sleep and descriptions of sleeping behaviors and settings 
What constituted "sleep" was not clearly defined in any of the documented studies. Methods of documentation, measurements or vocabulary and concepts used to describe sleep varied among the studies. As shown in Table 1, the 15 studies represent a wide range of different hospital units, and the parents' sleeps at different locations. The number of parents included in the studies varies from 12 to 211 parents, the location of parental accommodations varied from sleeping in the child's bed or in a mattress bedside, waiting room area, in a parent's room or lounge in the hospital, in a nearby hotel, or in a Ronald McDonald House.

\section{Design and methodology}

As shown in Table 1, the articles included in this review also represent a range of different designs. Most studies used a cross sectional design (Kim et al., 2017; McCann, 2008; McLoone et al., 2013; Meltzer et al., 2012). One study used an explorative design (Edéll-Gustafsson et al., 2015), one study has a longitudinal design (Blomqvist et al., 2017), two have a qualitative and prospective, descriptive design (Angelhoff et al., 2017; Heinemann et al., 2013), one study is a pilot study (Franck et al., 2014), and three studies used a prospective observational design, two qualitative and one quantitative. Ten of the studies used mixed methods, combining quantitative and qualitative data in the same study. Data were collected from interviews, questionnaires, sleep diaries, actigraphy devices, sound level monitoring, and medical charts.

\section{Themes}

Three overall themes were identified in the studies: parents' sleep quality (Table 2); factors effecting parents' sleep in the hospital (Table 3); and consequences of sleep loss (Table 4). Several studies found combined psychological factors to be affecting sleep of parents staying overnight in the hospital (Kim et al., 2017; Stremler et al., 2011). Others identify isolated psychological factors where parents report stress (Edéll-Gustafsson et al., 2015), anxiety (Edéll- 
Gustafsson et al., 2015; McLoone et al., 2013), uncertainty, worries (Lisa J. Meltzer et al., 2012), and difficult thoughts (Stremler et al., 2011). Environmental factors in the ward such as noise, illumination, and ward schedules are also emphasized in several studies (Angelhoff et al., 2017; Bevan et al., 2019; Edéll-Gustafsson et al., 2015; Heinemann et al., 2013; Kim et al., 2017; McLoone et al., 2013; Stickland et al., 2016; R. Stremler et al., 2011). Specifically identified social factors are: the importance of keeping the family together (Edéll-Gustafsson et al., 2015), the lack of a sufficiently private sphere (Heinemann et al., 2013), caring for oneself and the family (Stremler et al., 2011), and how parents manage and prevent tiredness (EdéllGustafsson et al., 2015).

\section{Conclusions of findings and recommendations made}

When reviewing the results of the study selection and their conclusions on factors related to the sleep of parents of hospitalized children, the issues are: loss of sleep, sleep disruption, and poor quality of sleep. The conclusions of the studies refer to the cohabiting with others, lack of privacy, noise and light when trying to sleep, and disruptions due to treatments and child-related and family factors as the factors affecting their sleep during the child's hospitalization. Several studies in the selection identify or recommend further studies in their conclusions and this is documented in Tables 2, 3, and Figure 3. These include: improving the measures of sleep, need for more in-depth interviews, and the inclusion of interventions. Some studies recommend future studies that should take into consideration the following factors: severity of the disease or illness of the child, sleep location of parents, better determination of the influencing factors on parents' sleep, and finally, the complexity of outcomes and long-term consequences of sleep deprivation and disruption to parents.

\section{Discussion}


This systematic integrative review brings together parents' experience and perception of sleep when they stay overnight in the hospitals together with their sick children. The three overall main themes appearing from the included studies are: sleep quality, factors affecting sleep, and consequences of sleep loss. Since the aims of the studies represent a broad range of themes, it is difficult to compare the different studies. They use different concepts and measure sleep, and sleep patterns with different methods.

It is interesting to note that there was no definition of sleep in any of the included studies. The studies used different terms referring to sleep, such as: sleep quality, sleep experience, the phenomena of sleep, sleep deprivation, sleep disruptions, sleep hours, and sleep duration. The lack of definitions of these terms results in obscuring a comparison of the studies. Good sleep is essential to good health, but sleep medicine has often focused on the definition, identification, and treatment of sleep problems (Buysse, 2014). It is well known that sustained absence of contiguous sleep periods has serious physiological and mental consequences (Institute of Medicine Committee on Sleep \& Research, 2006), and short sleep duration is associated with all-cause mortality and severe morbidity (Morris et al., 2012). Although several theories exist about why we sleep, there is still no consensus about the function of sleep. Normal consecutive sleeping periods vary between five to eight hours (Aurora, Kim, Crainiceanu, O'Hearn, \& Punjabi, 2016), and how much sleep each person needs varies.

Of note, it is not possible to compare parents' sleep in the included studies, since the locations of parent's accommodations varied from sleeping in the child's bed or in a chair in a waiting room, to a parent's room or lounge in the hospital, or in a nearby hotel. The reported results in this review are thus found to be conflicted.

There are some conflicting findings about parents' sleep quality in the hospitals (Table 3). In six of the studies the parents reported poor sleep quality and disrupted and fragmented sleep during the hospitalization (Franck et al., 2014; McCann, 2008; McLoone et al., 2013; Meltzer, 
Davis, et al., 2012; Stickland et al., 2016; Stremler et al., 2014, Nassery et al., 2018, Bevan et al., 2019). In one study, more than half of the parents reported good sleep quality in the pediatric ward despite nocturnal awakenings (Angelhoff et al., 2017). However, in that study, all families, except two, were accommodated in single patient rooms, which could have had a positive impact on sleep. Parents' sleep during the hospitalization can be challenging when sharing a room with several other parents and children (Meltzer et.al 2012). In addition, two of the studies document that participation in care duties increased the number of disturbances during the night (McLoone et al., 2013; Stremler et al., 2011).

In addition to the documentation of sleep loss during the child's hospitalization, sleep disruption is documented in all of these studies as affecting the duration of sleep. Factors affecting parents' sleep were different types of environmental noises made by staff (such as door slamming, lights, talking outside of the room) or a roommate making noises. Parents who slept at the ward or bedside also reported medical treatment and ward schedules (such as vital sign checks) as factors affecting sleep (Meltzer et al., 2012). This is consistent with another study asking nurses about factors affecting sleep. Four main influences on sleep were identified: child factors, environmental factors, nurse-parent interaction factors, and nursing care factors (Stremler, Adams, \& Dryden-Palmer, 2015). Since sleep is necessary for cognitive abilities such as: learning capability, concentration, memory function, and controlling emotional and physiological reactions (Morris, et.al., 2012) sustained absence of continuous periods of sleep may has serious physiological and mental consequences (Koren, et.al.,2016; OrzelGryglewska, 2010; Porkka-Heiskanen, Zitting, \& Wigren, 2013).

Having only one child in the hospital room was in one study found to be the single isolated factor that influenced the quality of parents' sleep (McCann, 2008). Although noises from staff and other children and parents interrupted the quality of sleep, several of the included studies identified factors such as parents' anxiety, worries and powerlessness about the child's health, 
and other child-related factors of importance. However, this is inconsistent with findings from a previous systematic review of parental stress during hospitalization due to chronic illness of a child. This study reveals that greater general parental stress is associated with greater parental responsibility for treatment management, and is unrelated to the duration of a child's illness or severity across illness populations (Cousino \& Hazen, 2013). The lack of a private environment is also a challenge and may influence parents', children's, and siblings' feelings when a child is hospitalized. However, as mentioned in the introduction, parental stay and participation during the child's hospitalization have been encouraged both by family interest groups and by health professionals for the last decades without considering the cost to the health and wellbeing of the parent.

All studies included were assessed according to one out of two quality assessment scales. The scales are meant to provide insight, and to assess whether we can trust the quality of the studies. Seven studies scored full, nine out of nine, or ten out of ten. Six studies scored with minor reductions in quality, with nine out of ten, or eight out of nine points; while three studies scored seven out of nine points on the quality assessment. These are all high scores regarding quality. However, both appraisal tools used in this systematic integrative review were originally developed from the viewpoint of practice, and not to identify the best evidence in a systematic literature study (EMBH Notebook 1998, MacDermid et al., 2009). This was the reason not to use its last three questions for the prevalence studies. This is a limitation in this review. It is important to note that the included studies have limited sample sizes. The cultural settings are limiting the studies due to the fact that they do not satisfactorily describe the cultural habits of hospitalization and rooming in the particular context of each study to a satisfactory degree. The research field of parents sleeping in the hospital with their children is still modest. All of the included studies except for two, are published from year 2012 and later. As the field is still developing, most of the research is explorative and descriptive. To date, there is no common 
agreement as to what constitutes and how to measure sleep amongst these parents. Small samples are quantified throughout the different studies. This makes the conclusions imprecise.

\section{Strengths and limitations}

A strength of this systematic integrative review is that the four research team members have been working together, sending the work back and forth, and have had Skype meetings for discussing in all phases of the review process. A previous study found that an increase in the numbers of reviewers will increase the possibility of bias in the assessment of quality of the included studies and the analysis of the results (Polkki, Kanste, Kaariainen, Elo, \& Kyngas, 2014). The review included only 15 manuscripts, which limits this review to a systematic integrative review due to scattered and inconclusive studies found on the subject. In addition, when scoring the quality assessment, only one methodology was examined, even if multiple methodologies were used in most of the studies. Ten of the studies used mixed methods, combining qualitative and quantitative data in the same study. However, this is not a critical limitation since the quality assessment scores are relatively high in the included studies.

\section{Conclusion}

From the results of this systematic integrative review of studies on the sleep that parents experience while staying with their child in the hospital, we conclude that the study of this subject is still in its exploratory phase. There is a need for the development of theory of substance in the clarification of the meaning of sleep among parents during difficult times such as children's hospitalization. There is also a need for more research on how parental sleep relates to the health and well-being of the parents. The lack of definitions and theory of sleep and related constructs, included in the studies of this review, is of concern and needs to be addressed in future studies on this subject.

\section{Relevance to Clinical Practice}


Understanding risk factors associated with sleep and sleep deprivation in parents' staying overnight in the hospital with their sick child is important, since lack of sleep may lead to serious stress-related outcomes for the parents. There is a need for more research into the impact of physiological, psychological, environmental and social factors of their stay in the hospital and their participation in their child's care. The findings tell us that assessing parental sleep needs to be developed and practiced in the care of children in hospitals. Interventions as to how and where parents can sleep during their hospital stay needs to be addressed in the clinical work and with clinical intervention studies of parents and children in hospitals.

\section{References}

Angelhoff, C., Edell-Gustafsson, U., \& Morelius, E. (2015). Sleep of Parents Living With a Child Receiving Hospital-Based Home Care: A Phenomenographical Study. Nursing Research, 64 (5), 372-380. doi:10.1097/nnr.0000000000000108

Angelhoff, C., Edell-Gustafsson, U., \& Morelius, E. (2017). Sleep quality and mood in mothers and fathers accommodated in the family-centred paediatric ward. Journal of Clinical Nursing, 27 (3-4), e544-e550. doi: 10.1111/jocn.14092

Atmawidjaja, R. W., Wong, S. W., Yang, W. W., \& Ong, L. C. (2014). Sleep disturbances in Malaysian children with cerebral palsy. Developmental Medicine \& Child Neurologi, 56 (7), 681-685. doi:10.1111/dmcn.12399

Aurora, R. N., Kim, J. S., Crainiceanu, C., O'Hearn, D., \& Punjabi, N. M. (2016). Habitual Sleep Duration and All-Cause Mortality in a General Community Sample. Sleep, 39 (11), 1903-1909. doi:10.5665/sleep.6212

Beck, A. F., Solan, L. G., Brunswick, S. A., Sauers-Ford, H., Simmons, J. M., Shah, S., . . . Sherman, S. N. (2017). Socioeconomic status influences the toll paediatric hospitalisations take on families: a qualitative study. BMJ Quality \& Safty, 26 (4), 304311. doi:10.1136/bmjqs-2016-005421

Bevan. R., Grantham-Hill S, Bowen R, Clayton, R., Grice, H., Venditti, H. C., Stickland A., \& Hill, C. M. (2019) Sleep quality and noise: comparisons between hospital and home settings Archives of Disease in Childhood, 104,147-151. doi:10.1136/archdischild2018-315168

Blomqvist, Y. T., Nyqvist, K. H., Rubertsson, C., \& Funkquist, E.-L. (2017). Parents need support to find ways to optimise their own sleep without seeing their preterm infant's sleeping patterns as a problem. Acta Pcediatrica, 106 (2), 223-228. doi:10.1111/apa.13660 
Buysse, D. J. (2014). Sleep health: can we define it? Does it matter? Sleep, 37 (1), 9-17. doi:10.5665/sleep.3298

CASP. (2014). Critical Appraisal Skills Programme. Retrieved April 13, 2018 from: https://casp-uk.net/

Colville, G., Darkins, J., Hesketh, J., Bennett, V., Alcock, J., \& Noyes, J. (2009). The impact on parents of a child's admission to intensive care: integration of qualitative findings from a cross-sectional study. Intensive and Critical Care Nursing, 25 (2), 72-79. doi:10.1016/j.iccn.2008.10.002

Commodari, E. (2010). Children staying in hospital: a research on psychological stress of caregivers. Italian Journal of Pediatrics, 36, 40. doi:10.1186/1824-7288-36-40

Cousino, M. K., \& Hazen, R. A. (2013). Parenting stress among caregivers of children with chronic illness: a systematic review. Journal of Pediatric Psychology, 38 (8), 809-828. doi:10.1093/jpepsy/jst049

Coyne, I. (2006). Children's experiences of hospitalization. Journal of Child Health Care, 10 (4), 326-336. doi:10.1177/1367493506067884

Dahav, P., \& Sjöström-Strand, A. (2017). Parents' experiences of their child being admitted to a paediatric intensive care unit: a qualitative study-like being in another world. Scandinavian Journal of Caring Science. doi:10.1111/scs.12470

Davies, R. (2010). Marking the 50th anniversary of the Platt Report: from exclusion, to toleration and parental participation in the care of the hospitalized child. Journal of Child Health Care, 14(1), 6-23. doi:10.1177/1367493509347058

Diffin, J., Spence, K., Naranian, T., Badawi, N., \& Johnston, L. (2016). Stress and distress in parents of neonates admitted to the neonatal intensive care unit for cardiac surgery. Early Human Development, 103, 101-107. doi:10.1016/j.earlhumdev.2016.08.002

Doering, J., \& Durfor, S. L. (2011). The process of "persevering toward normalcy" after childbirth. MCN American Journal of Maternal/Child Nursing, 36 (4), 258-265. doi:10.1097/NMC.0b013e31821826e7

Edéll-Gustafsson, U., Angelhoff, C., Johnsson, E., Karlsson, J., \& Mörelius, E. (2015). Hindering and buffering factors for parental sleep in neonatal care. A phenomenographic study. Journal of Clinical Nursing, 24 (5/6), 717-727. doi:10.1111/jocn.12654

EMBH Notebook (1998). Guidelines for evaluating prevalensestudies. Retrieved March 27, 2018 from: http://ebmh.bmj.com/content/ebmental/1/2/37.full.pdf

Franck, L., Wray, J., Gay, C., Dearmun, A. K., Alsberge, I., \& Lee, K. A. (2014b). Where do parents sleep best when children are hospitalized? A pilot comparison study. Behavioral Sleep Medicine, 12 (4), 307-316. doi:10.1080/15402002.2013.801347 
Heinemann, A. B., Hellstrom-Westas, L., \& Hedberg Nyqvist, K. (2013). Factors affecting parents' presence with their extremely preterm infants in a neonatal intensive care room. Acta Pcediatrica, 102 (7), 695-702. doi:10.1111/apa.12267

Institute of Medicine Committee on Sleep, M., \& Research. (2006). The National Academies Collection: Reports funded by National Institutes of Health. In H. R. Colten \& B. M. Altevogt (Eds.), Sleep Disorders and Sleep Deprivation: An Unmet Public Health Problem. Washington (DC): National Academies Press (US) National Academy of Sciences.

Kim, S. J., Kim, H. Y., Park, Y. A., Kim, S. H., Yoo, S. Y., Lee, J. E., \& Moon, S. Y. (2017). Factors influencing fatigue among mothers with hospitalized children: A structural equation model. Journal for Specialists in Pediatric Nursing, 22 (1). 1-9. doi: $10.1111 /$ jspn. 12171

Koren, D., Dumin, M., \& Gozal, D. (2016). Role of sleep quality in the metabolic syndrome. Diabetes Metabolic Syndrome and Obesity, 9, 281-310. doi:10.2147/dmso.s95120

Norwegian institute of public health 2017, Quality assessment retrieved April 10, from; https://www.fhi.no/globalassets/kss/filer/filer/verktoy/sjekkliste_prevalensstudier_206. pdf

McCann, D. (2008). Sleep deprivation is an additional stress for parents staying in Hospital. Journal for Specialists in Pediatric Nursing, 13 (2), 111-122. doi:10.1111/j.1744-6155.2008.00142.x

MacDermid J.C., Walton D.M. \& Law M. (2009) Critical appraisal of research evidence for its validity and usefulness. Hand Clinics 25(1), 29-42

McLoone, J. K., Wakefield, C. E., Yoong, S. L., \& Cohn, R. J. (2013). Parental sleep experiences on the pediatric oncology ward. Supportive Care in Cancer, 21 (2), 557564. doi:10.1007/s00520-012-1547-z

Meltzer, L. J., Biggs, S., Reynolds, A., Avis, K. T., Crabtree, V. M., \& Bevans, K. B. (2012). The Children's Report of Sleep Patterns-Sleepiness Scale: A self-report measure for school-aged children. Sleep Medicine, 13(4), 385-389. doi: 10.1016/j.sleep.2011.12.004

Meltzer, L. J., Davis, K. F., \& Mindell, J. A. (2012). Patient and parent sleep in a children's hospital. Pediatric Nursing, 38 (2), 64-71; quiz 72.

Meltzer, L. J., \& Moore, M. (2008). Sleep disruptions in parents of children and adolescents with chronic illnesses: prevalence, causes, and consequences. Journal of Pediatric Psychololgy, 33 (3), 279-291. doi:10.1093/jpepsy/jsm118

Morris, C. J., Aeschbach, D., \& Scheer, F. A. (2012). Circadian system, sleep and endocrinology. Molecular and Cellular Endocrinology, 349 (1), 91-104. doi:10.1016/j.mce.2011.09.003 
Nassery, W. \& Landgren K. (2018). Parents' Experience of Their Sleep and Rest When Admitted to Hospital with Their Ill Child: A Qualitative Study. Comprehensive Child and Adolescent Nursing, 2, 1-15. doi: 10.1080/24694193.2018.1528310

Notebook, E. (1998). Guidelines for evaluating prevalence studies Retrieved September 9, 2019, from http://ebmh.bmj.com/content/ebmental/1/2/37.full.pdf

Orzel-Gryglewska, J. (2010). Consequences of sleep deprivation. International Journal of Occupational Medicine and Environmental Health, 23 (1), 95-114. doi:10.2478/v10001-010-0004-9

Oxley, R. (2015). Parents' experiences of their child's admission to paediatric intensive care. Nursing Children and Young People, 27 (4), 16-21. doi:10.7748/ncyp.27.4.16.e564

Placencia, F. X., \& McCullough, L. B. (2012). Biopsychosocial risks of parental care for high-risk neonates: implications for evidence-based parental counseling. Journal of Perinatology, 32 (5), 381-386. doi:10.1038/jp.2011.109

Porkka-Heiskanen, T., Zitting, K. M., \& Wigren, H. K. (2013). Sleep, its regulation and possible mechanisms of sleep disturbances. Acta Physiologica, 208 (4), 311-328. doi:10.1111/apha.12134

Power, N., \& Franck, L. (2008). Parent participation in the care of hospitalized children: a systematic review. Journal of Advanced Nursing, 62 (6), 622-641. doi: 10.1111/j.1365-2648.2008.04643.x

Polkki, T., Kanste, O., Kaariainen, M., Elo, S., \& Kyngas, H. (2014). The methodological quality of systematic reviews published in high-impact nursing journals: a review of the literature. Journal of Clinical Nursing, 23 (3-4), 315-332. doi:10.1111/jocn.12132

PRISMA. Prisma 2009 Checklist. Retrieved April 13, 2019 http://prismastatement.org/PRISMAStatement/

Stickland, A., Clayton, E., Sankey, R., \& Hill, C. M. (2016). A qualitative study of sleep quality in children and their resident parents when in hospital. Archives of Disease in Childhood, 101 (6), 546-551. doi:10.1136/archdischild-2015-309458

Stremler, R., Adams, S., \& Dryden-Palmer, K. (2015). Nurses' views of factors affecting sleep for hospitalized children and their families: A focus group study. Research in Nursing \& Health, 38 (4), 311-322. doi:10.1002/nur.21664

Stremler, R., Dhukai, Z., Pullenayegum, E., Weston, J., Wong, L., \& Parshuram, C. (2014). Sleep, sleepiness, and fatigue outcomes for parents of critically ill children. Pediatric Critical Care Medicine, 15 (2), e56-65. doi:10.1097/01.pcc.0000436198.15337.15

Stremler, R., Dhukai, Z., Wong, L., \& Parshuram, C. (2011). Factors influencing sleep for parents of critically ill hospitalised children: a qualitative analysis. Intensive $\&$ Critical Care Nursing, 27 (1), 37-45. doi:10.1016/j.iccn.2010.11.001 
Stremler, R., Haddad, S., Pullenayegum, E., \& Parshuram, C. (2017). Psychological Outcomes in Parents of Critically Ill Hospitalized Children. Journal of Pediatric Nursing, 34, 36-43. doi:10.1016/j.pedn.2017.01.012

Stremler, R., Wong, L., \& Parshuram, C. (2008). Practices and provisions for parents sleeping overnight with a hospitalized child. Journal of Pediatric Psychology, 33 (3), 292-297. doi:10.1093/jpepsy/jsm096

Toffalini, E., Veltri, A., \& Cornoldi, C. (2015). Metacognitive aspects influence subjective well-being in parents of children with cancer. Psychooncology, 24 (2), 175-180. doi:10.1002/pon.3622

Woolf, C., Muscara, F., Anderson, V. A., \& McCarthy, M. C. (2016). Early Traumatic Stress Responses in Parents Following a Serious Illness in Their Child: A Systematic Review. Journal of Clinical Psychology in Medical Settings, 23 (1), 53-66. doi:10.1007/s10880-015-9430-y 


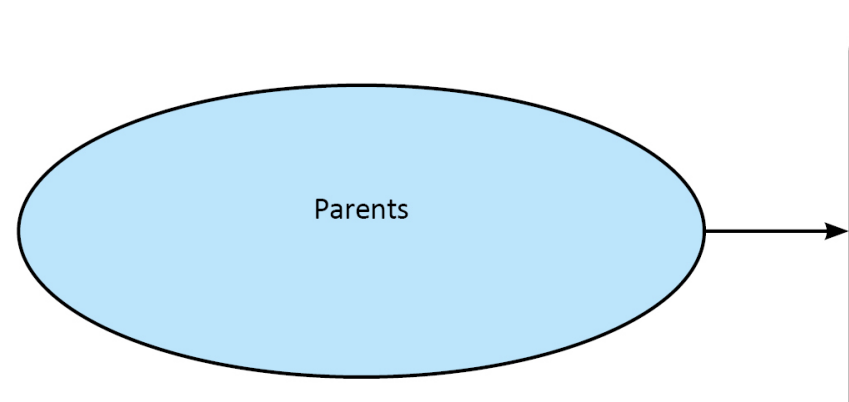

Parent* Parental

Kin next of kin

Family (member*)

Relative*

Mother* Father*

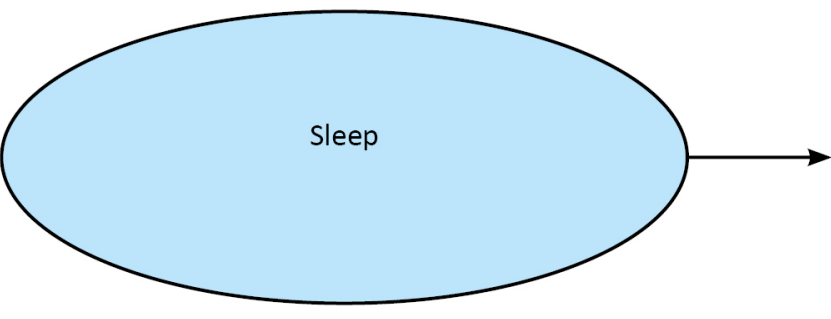

Sleep* (-ing, iness)

(pattern, experiences, habits, quality, evaluation, disturbance, ...)

Slept Sleepness* (-ness) Wake* and night* Awake* and night* Wakeful* and night*

Kid Kids

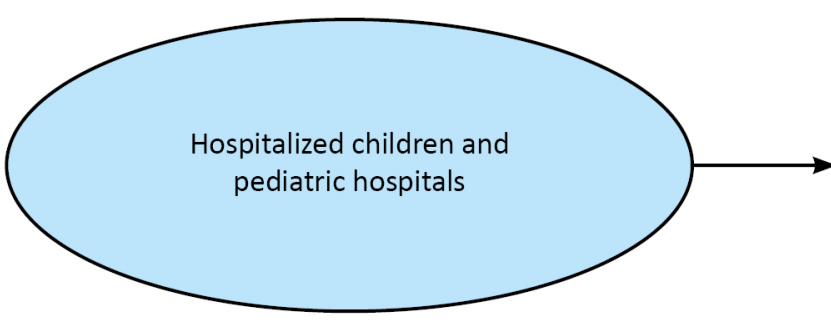

Newborn Toddler* Preschool, Adolcent* Infant* Teenager Youngster Youth

Hospitali* and child* Institutionali* and child* Inpatient* and child*

Pediatric and ward* Pediatric and unit* Department of pediatrics Children* and hospital* Pediatric and hospital* 


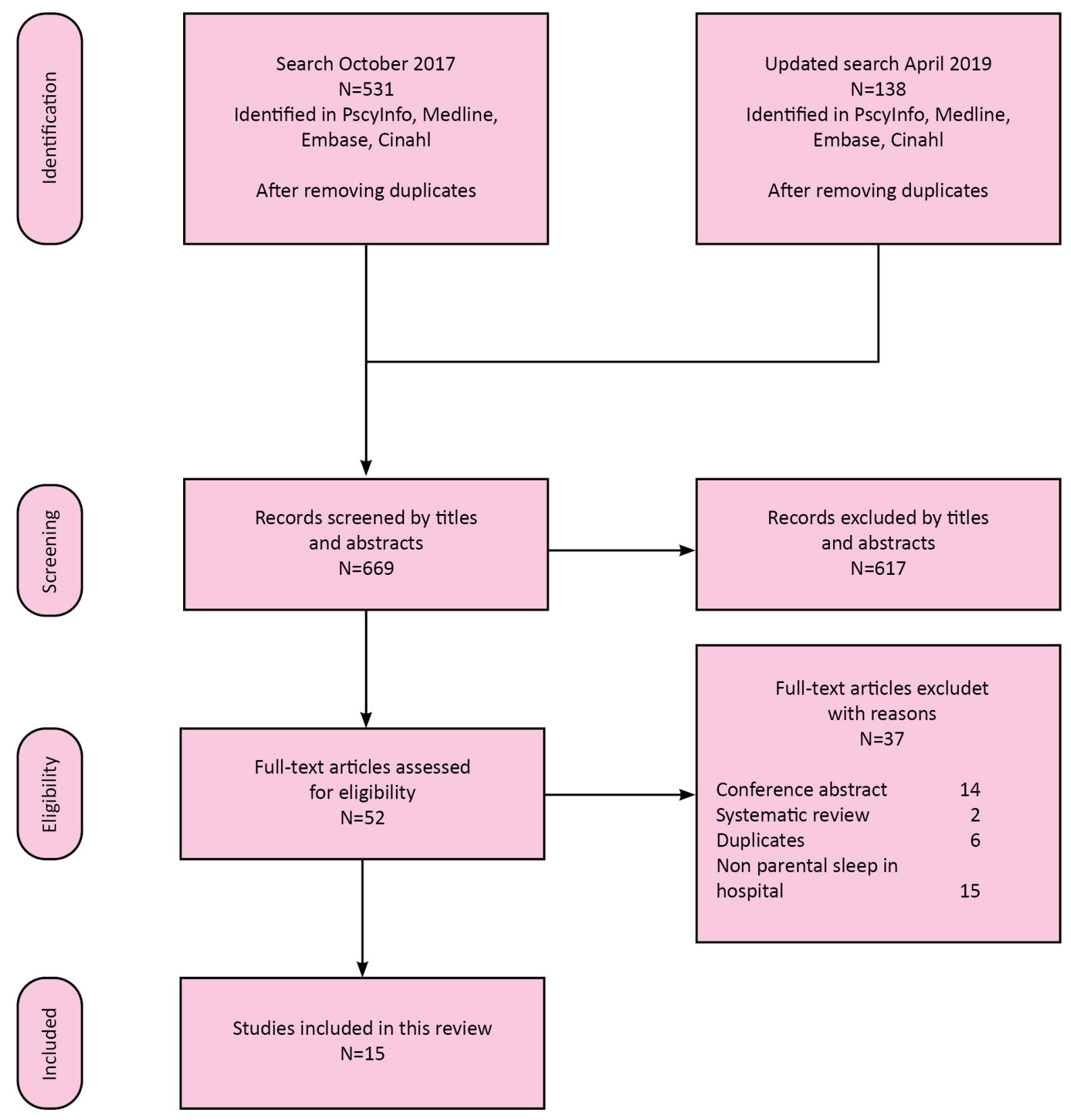


Angelhoff,

Edéll-Gustafsson, and

Mörelius, 2017.
Poor sleep quality correlated with negativ mood. The parents were less alert, less interested, and had reduced concentration, and were more tired, dull and passive in the hospital than at home.
A qualitative interview study to optain a deeper understanding of parents' sleep quality, mood and coping strategies when they stay overnight in a pediatric ward.

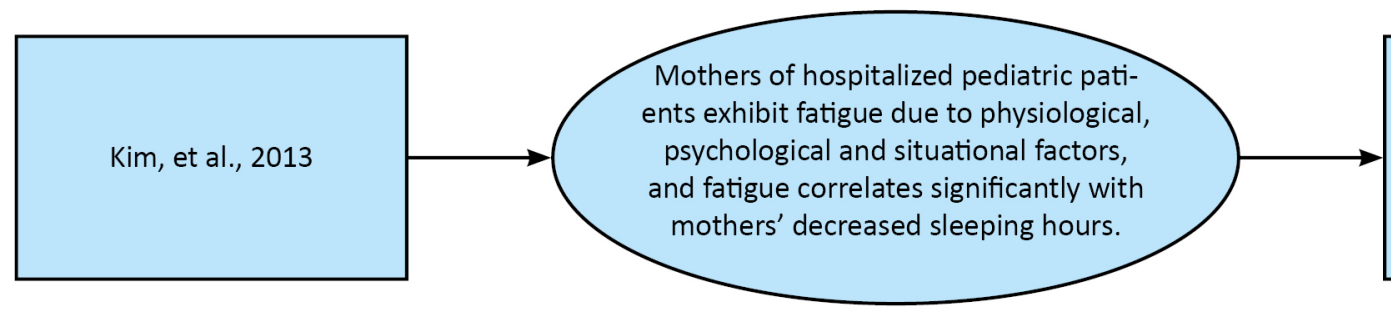

Furhter studies are needed to explore the effect of variables (such as the type or severity of the diseases, and the number of children at home) on the fatigue of mothers with hospitalized children.
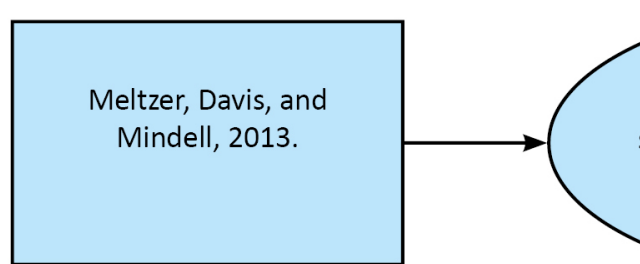

Sleep plays an important role in the health and well-being of patients and their parents. For parents, sufficient good quality sleep contributes to the ability to make important medical decisions and provide emotional support for their child.
Stickland, Clayton, Sankey, and Hill, 2016.
Parents reported that lack of sleep caused difficulties with their own emotional regulation, as well as their child's, affecting daytime parent-child relationships.
Pullenayegum, and Parshuram, 2017.
Social support, inconsistency in sleep schedule and duration, and sleep location affected psychological outcomes.

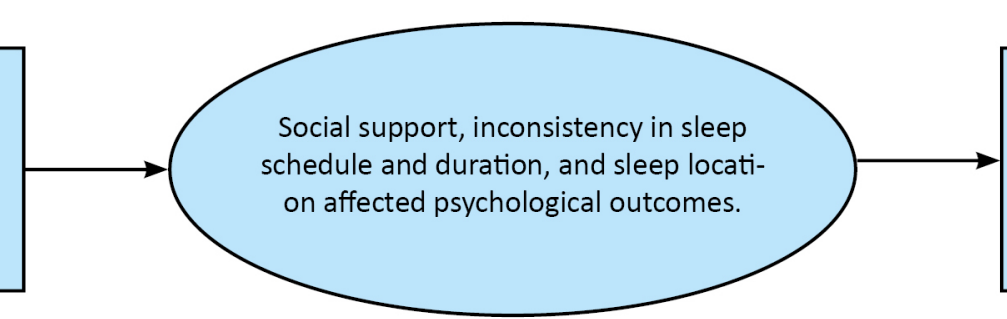

This study demonstrates the need for additional research examining the causes and consequences of disrupted sleep for patients and parents in a children's hospital.

No recommandations.

Future studies should examine the effects of hosptalization on long-term parental psychological outcomes and inconsistency in sleep schedule and sleep location. 
Table 1. Overview of included studies

\begin{tabular}{|c|c|c|c|c|c|c|}
\hline & Aim & $\begin{array}{l}\text { Design/ method } \\
\text { Measurement/interview } \\
\text { methods }\end{array}$ & $\begin{array}{l}\text { Persons included / } \\
\text { sample } \\
\text { Age of the sick } \\
\text { child }\end{array}$ & $\begin{array}{l}\text { Hospital/ department } \\
\text { Where do parents stay } \\
\text { overnight }\end{array}$ & Reported limitations & $\begin{array}{l}\text { Quality } \\
\text { scores }\end{array}$ \\
\hline $\begin{array}{l}\text { Angelhoff, Edéll- } \\
\text { Gustavsson, and } \\
\text { Mörelius (2017) } \\
\text { Sweden }\end{array}$ & $\begin{array}{l}\text { a. To describe sleep quality and } \\
\text { mood in parents admitted to the } \\
\text { hospital together with their } \\
\text { sick child. } \\
\text { b. To compare mothers' and } \\
\text { fathers' sleep quality and mood in } \\
\text { the pediatric ward to their daily-life } \\
\text { home setting after discharge. }\end{array}$ & $\begin{array}{l}\text { Prospective and descriptive study. } \\
\text { a. Uppsala sleep inventory (USI), } \\
\text { b. Sleep diary, } \\
\text { c. Sleep log and interview four weeks } \\
\text { later, } \\
\text { d. Mood adjective checklist (MACL). }\end{array}$ & $\begin{array}{l}82 \text { parents }(61 \\
\text { mothers and } 21 \\
\text { fathers). } \\
79 \text { children (median } \\
\text { age } 6.25 \text { years). }\end{array}$ & $\begin{array}{l}\text { At } 6 \text { family-centered } \\
\text { pediatric wards, children } \\
\text { from } 0 \text { - } 18 \text { years. } \\
\text { Bedside in hospital and } \\
\text { home }\end{array}$ & $\begin{array}{l}\text { It was difficult to enroll } \\
\text { parents since their children } \\
\text { were the primary focus of } \\
\text { the hospital admission. A } \\
\text { selection bias could be that } \\
\text { the participants were the } \\
\text { most alert parents and that } \\
\text { those who were tired may } \\
\text { have declined participation } \\
\text { rendering a non- } \\
\text { representative sample of } \\
\text { parents accommodating } \\
\text { with their child. }\end{array}$ & $9 / 10$ \\
\hline $\begin{array}{l}\text { Bevan, Grantham-Hill, } \\
\text { Bowen, Clayton, Grice, } \\
\text { Venditti, Stickland, and } \\
\text { Hill (2019) } \\
\text { England /UK }\end{array}$ & $\begin{array}{l}\text { a. To objectively measure the sleep } \\
\text { quality - sleep time and sleep } \\
\text { efficiency - of co-sleeping parents } \\
\text { in pediatric wards. } \\
\text { b. Compare it to their sleep in their } \\
\text { home. } \\
\text { c. To measure sound levels at the } \\
\text { bedside in the hospital and home. }\end{array}$ & $\begin{array}{l}\text { Prospective descriptive design. } \\
\text { a. Demographic information, } \\
\text { b. Actigraphy in home before, during } \\
\text { and after child's hospitalization, } \\
\text { c. Sound level monitoring at home } \\
\text { and at bedside of parents, } \\
\text { d. Sleep diary. }\end{array}$ & $\begin{array}{l}16 \text { mothers (mean age } \\
37.9 \text { years). }\end{array}$ & $\begin{array}{l}\text { At } 6 \text { pediatric medical } \\
\text { wards in a regional } \\
\text { children's hospital in South } \\
\text { England }\end{array}$ & $\begin{array}{l}\text { Only half of the recruited } \\
\text { parents fully participated. } \\
\text { Sample small and measures } \\
\text { made for fewer than } 5 \\
\text { nights and not controlling } \\
\text { for variability and } \\
\text { disturbances. }\end{array}$ & $9 / 9$ \\
\hline $\begin{array}{l}\text { Blomqvist, Nyqvist, } \\
\text { Rubertsson, and } \\
\text { Funkquist (2017) } \\
\text { Sweden }\end{array}$ & $\begin{array}{l}\text { a. To describe parents' perception } \\
\text { of } \\
\text { - their own sleep, and } \\
\text { - their infants', } \\
\text { during NICU admission and } \\
\text { following discharge. } \\
\text { b. Explore the infants' sleeping } \\
\text { location at home. }\end{array}$ & $\begin{array}{l}\text { Longitudinal study - register data and } \\
\text { survey. } \\
\text { a. Infants' medical chart review, } \\
\text { b. Swedish Neonatal Quality Register, } \\
\text { c. Insomnia Severity Index (ISI), and } \\
\text { d. One additional question asking } \\
\text { whether parents felt they got enough } \\
\text { sleep. }\end{array}$ & $\begin{array}{l}170 \text { parents }(86 \\
\text { mothers and } 84 \\
\text { fathers). } \\
86 \text { infant births, } \\
\text { discharged at age, }-2 \text {, } \\
6 \text { and } 12 \text { month } \\
\text { corrected age. }\end{array}$ & $\begin{array}{l}\text { NICU } \\
\text { Bedside in hospital and } \\
\text { home }\end{array}$ & $\begin{array}{l}\text { The limitations of this study } \\
\text { are the comparative study } \\
\text { design and the inability to } \\
\text { control for differences in } \\
\text { routines between the } \\
\text { NICU's. }\end{array}$ & $10 / 10$ \\
\hline $\begin{array}{l}\text { Edéll-Gustavsson, } \\
\text { Angelhoff, Johnsson, } \\
\text { Karlsson, and Mörelius } \\
\text { (2015) }\end{array}$ & $\begin{array}{l}\text { To explore and describe how } \\
\text { parents of preterm and/or sick } \\
\text { infants in NICU perceive their } \\
\text { sleep. }\end{array}$ & $\begin{array}{l}\text { A phenomenographic study with an } \\
\text { inductive and exploratory design. } \\
\text { A qualitative, semi-structured } \\
\text { interview with each parent. }\end{array}$ & $\begin{array}{l}12 \text { parents ( } 8 \text { mothers } \\
\text { and } 4 \text { fathers). }\end{array}$ & $\begin{array}{l}\text { NICU } \\
8 \text { parents' bedside, and } \\
4 \text { parents in a parent room } \\
\text { close to the ward }\end{array}$ & $\begin{array}{l}\text { Neonatal care might differ } \\
\text { depending on culture and } \\
\text { hospital policies, which } \\
\text { could affect the findings. } \\
\text { Furthermore, parents in }\end{array}$ & $9 / 9$ \\
\hline
\end{tabular}




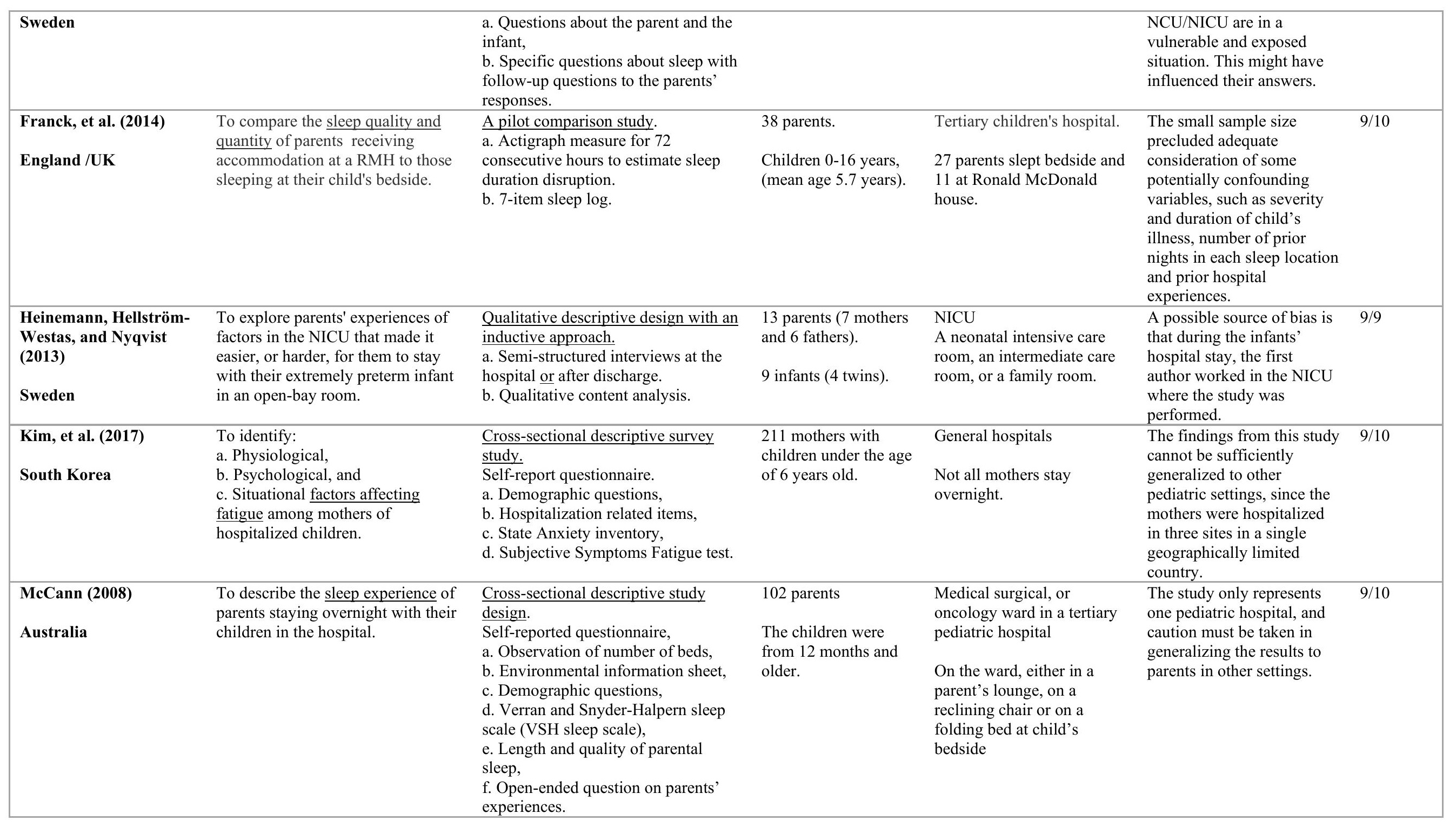




\begin{tabular}{|c|c|c|c|c|c|c|}
\hline $\begin{array}{l}\text { McLoone, Wakefield, } \\
\text { Yoong, and Cohn (2013) } \\
\text { Australia }\end{array}$ & $\begin{array}{l}\text { To provide: } \\
\text { a. The first prevalence estimates of } \\
\text { parent-reported sleep quality and } \\
\text { quantity when accommodated on } \\
\text { the pediatric oncology ward, and } \\
\text { b. Determine predictors of poor } \\
\text { sleep among this group compared to } \\
\text { parents of age-matched controls. }\end{array}$ & $\begin{array}{l}\text { Quantitative Descriptive Comparative } \\
\text { study. } \\
\text { a. St. Mary's Hospital Sleep } \\
\text { Questionnaire, } \\
\text { b. The depression Anxiety Stress } \\
\text { Scale, } \\
\text { c. Demographic, clinical and } \\
\text { situational information (such as } \\
\text { number of people sharing room) were } \\
\text { collected with using standarized } \\
\text { items, } \\
\text { d. Qualitative data from open-ended } \\
\text { questions. }\end{array}$ & $\begin{array}{l}114 \text { parents ( } 52 \\
\text { parents of children } \\
\text { with cancer and } 62 \\
\text { healthy controls). } \\
\text { Children average age } \\
7.4 \text { years. }\end{array}$ & $\begin{array}{l}\text { Pediatric oncology ward } \\
\text { On the oncology ward }\end{array}$ & $\begin{array}{l}\text { This study was limited in its } \\
\text { reliance on self-reported } \\
\text { assessment of sleep. }\end{array}$ & $10 / 10$ \\
\hline $\begin{array}{l}\text { Meltzer, Davis, and } \\
\text { Mindell (2012) } \\
\text { United States }\end{array}$ & $\begin{array}{l}\text { To capture multiple aspects of sleep } \\
\text { in parents during a night in a } \\
\text { children's hospital. }\end{array}$ & $\begin{array}{l}\text { Quantitative cross-sectional study. } \\
\text { Self-created and self-reported } \\
\text { questionnaire to parents about: } \\
\text { a. sleep patterns of parent and child, } \\
\text { b. sleep disturbances of parent and } \\
\text { child. }\end{array}$ & $\begin{array}{l}52 \text { parents. } \\
72 \text { children average } \\
\text { age } 13.1 \text { years }(8-21 \\
\text { years). }\end{array}$ & $\begin{array}{l}\text { Tertiary care children's } \\
\text { hospital } \\
\text { Rooming-in }\end{array}$ & $\begin{array}{l}\text { This study only captured } \\
\text { one night of parents' sleep } \\
\text { in the hospital. The data } \\
\text { was self-reported with no } \\
\text { objective measures. }\end{array}$ & $8 / 10$ \\
\hline $\begin{array}{l}\text { Nassery and Landgren } \\
\text { (2018) } \\
\text { Sweden }\end{array}$ & $\begin{array}{l}\text { To explore parents' experiences of } \\
\text { sleep and rest while admitted to the } \\
\text { hospital together with their ill child. }\end{array}$ & $\begin{array}{l}\text { Qualitative. } \\
\text { a. semi-structured audio-taped } \\
\text { interviews at the hospital in child's } \\
\text { room or consultation room, } \\
\text { b. Latent content analysis, } \\
\text { c. Excluding those not speaking } \\
\text { Swedish. }\end{array}$ & $\begin{array}{l}17 \text { parents ( } 12 \\
\text { mothers and } 5 \text { fathers) } \\
9 \text { individual } \\
\text { interviews } \\
4 \text { couple interviews } \\
23-46 \text { minutes } \\
\text { Age of child: one } \\
\text { month-15 years } \\
13 .\end{array}$ & $\begin{array}{l}\text { 10-unit pediatric section in } \\
\text { a general hospital in South } \\
\text { Sweden } \\
6 \text { units participated } \\
\text { Stay in hospital is from } 1 \\
\text { night to } 3 \text { months } \\
13 \text { parents stayed at the } \\
\text { ward during night with } \\
\text { child } \\
4 \text { parents stayed at the } \\
\text { RMH }\end{array}$ & $\begin{array}{l}\text { A varying stay of parents } \\
\text { and health condition of their } \\
\text { children as well as a small } \\
\text { sample. Only two reading } \\
\text { the interviews and no } \\
\text { generalizability. }\end{array}$ & $9 / 9$ \\
\hline $\begin{array}{l}\text { Stickland, Clayton, } \\
\text { Sankey, and Hill (2016) } \\
\text { England /UK }\end{array}$ & $\begin{array}{l}\text { To study the experiences of } \\
\text { children and parents during hospital } \\
\text { admissions. }\end{array}$ & $\begin{array}{l}\text { A multi-method study. } \\
\text { Qualitative, Grounded theory. } \\
\text { a. Semi-structured interviews, } \\
\text { b. Child sleep habits questionnaire, } \\
\text { c. Medical record data: Diagnoses and } \\
\text { reasons for admissions. }\end{array}$ & $\begin{array}{l}17 \text { parents }(16 \\
\text { mothers one father) } \\
\text { of } 16 \text { children mean } \\
\text { age } 7 \text { years ( } 3-12 \\
\text { years). }\end{array}$ & $\begin{array}{l}\text { Medical ward } \\
\text { at a children's hospital } \\
\text { Bedside }\end{array}$ & $\begin{array}{l}\text { Potential researcher bias } \\
\text { and a small sample size. It } \\
\text { is difficult to generalize to } \\
\text { other pediatric ward } \\
\text { settings. } \\
\text { They did not screen the } \\
\text { parents for sleep disorders. }\end{array}$ & $8 / 9$ \\
\hline $\begin{array}{l}\text { Stremler, et al. (2014) } \\
\text { Canada }\end{array}$ & $\begin{array}{l}\text { To describe sleep quantity, sleep } \\
\text { patterns, fatigue, and sleepiness for } \\
\text { parents of critically ill hospitalized } \\
\text { children. }\end{array}$ & $\begin{array}{l}\text { Quantitative. } \\
\text { Prospective observational study using } \\
\text { subjective and objective data. } \\
\text { a. Actigraphy, } \\
\text { b. Sleep diary, }\end{array}$ & $\begin{array}{l}118 \text { parents }(74 \\
\text { mothers and } 44 \\
\text { fathers) of } 91 \\
\text { critically ill children. }\end{array}$ & $\begin{array}{l}\text { PICU } \\
\text { Sleeping in a hotel, parent } \\
\text { room, residence hospital, } \\
\text { lounge, or waiting room. }\end{array}$ & $\begin{array}{l}\text { They did not ask parents to } \\
\text { report the number of } \\
\text { nocturnal awakenings they } \\
\text { experienced, so they did not } \\
\text { know the number of } \\
\text { awaking's assessed by }\end{array}$ & $8 / 10$ \\
\hline
\end{tabular}




\begin{tabular}{|c|c|c|c|c|c|c|}
\hline & & $\begin{array}{l}\text { c. The Stanford Sleepiness Scale, } \\
\text { register of sleep location. }\end{array}$ & & & $\begin{array}{l}\text { actigraphy and those } \\
\text { remembered by parents. }\end{array}$ & \\
\hline $\begin{array}{l}\text { Stremler, Haddad, } \\
\text { Pullenayegum, and } \\
\text { Parshuram (2017) } \\
\text { Canada }\end{array}$ & $\begin{array}{l}\text { During a child's hospitalization in } \\
\text { the PICU: } \\
\text { a. to ascertain the prevalence and } \\
\text { b. identify factors } \\
\text { of anxiety, depressive symptoms } \\
\text { and decisional conflict in parents. }\end{array}$ & $\begin{array}{l}\text { Quantitative Observational study. } \\
\text { a. Measures of anxiety (STAI), } \\
\text { b. Depression (CES-D), } \\
\text { c. Decisional conflict (DCS), } \\
\text { d. Hospital data, } \\
\text { e. Sleep diary, and } \\
\text { f. Actigraph. }\end{array}$ & $\begin{array}{l}118 \text { parents }(74 \\
\text { mothers and } 44 \\
\text { fathers) of } 91 \text { PICU } \\
\text { children } \\
\text { (0-18 years old; } 54 \% \\
<1 y) \text {. }\end{array}$ & $\begin{array}{l}\text { 36-bed quaternary-level } \\
\text { PICU in an urban, research- } \\
\text { intensive pediatric hospital }\end{array}$ & $\begin{array}{l}\text { The study sample was } \\
\text { comprised of predominantly } \\
\text { well-educated, partnered, } \\
\text { and English-speaking } \\
\text { families from a single site. }\end{array}$ & $8 / 10$ \\
\hline $\begin{array}{l}\text { Stremler, Dhukai, } \\
\text { Wong, and Parshuram } \\
\text { (2011) } \\
\text { Canada }\end{array}$ & $\begin{array}{l}\text { To describe factors affecting the } \\
\text { sleep of parents of critically ill } \\
\text { children and to determine strategies } \\
\text { used to improve their sleep. }\end{array}$ & $\begin{array}{l}\text { Qualitative } \\
\text { prospective, observational study } \\
\text { Answers in writing to open-ended } \\
\text { questions provided by staff assessing } \\
\text { their experiences with sleep. }\end{array}$ & $\begin{array}{l}118 \text { parents } \\
\text { of } 91 \text { children. }\end{array}$ & $\begin{array}{l}\text { PICU } \\
\text { Of the } 497 \text { parent nights } \\
\text { with information about } \\
\text { sleep location, } 38 \% \text { at } \\
\text { home, } 41 \% \text { in a parent room } \\
\text { in hospital/nearby } \\
\text { hotel/residence designated } \\
\text { for parents, } 12 \% \text { at child's } \\
\text { bedside, } 8 \% \text { a hospital } \\
\text { lounge/waiting room and } \\
1 \% \text { in the child's bed. }\end{array}$ & $\begin{array}{l}\text { No demographic data } \\
\text { presented on parents who } \\
\text { did not wish to enter the } \\
\text { study. Response rate } 58 \% \text {. }\end{array}$ & $9 / 9$ \\
\hline
\end{tabular}


Table 2. Reported results and recommendations of studies addressing parents' sleep quality in the hospital with their child.

\begin{tabular}{|c|c|c|c|}
\hline Author & Year & Results/Conclusions & Future research \\
\hline $\begin{array}{l}\text { Angelhoff, } \\
\text { Edéll-Gustafsson } \\
\text { and Mörelius }\end{array}$ & 2017 & $\begin{array}{l}\text { The parents had good sleep quality } \\
\text { in the pediatric ward even though } \\
\text { they had more awakenings } \\
\text { compared to at home. }\end{array}$ & $\begin{array}{l}\text { To complement these subjective } \\
\text { measures of sleep, future research should } \\
\text { include objective measures, such as } \\
\text { cortisol awakening response and } \\
\text { actigraphy. } \\
\text { Also recommended is a qualitative } \\
\text { interview study to obtain a deeper } \\
\text { understanding of parents' sleep quality, } \\
\text { mood and coping strategies when they } \\
\text { stay overnight in a pediatric ward. }\end{array}$ \\
\hline $\begin{array}{l}\text { Bevan, Grantham- } \\
\text { Hill, Bowen, } \\
\text { Clayton, Grice, } \\
\text { Venditti, Stickland, } \\
\text { and Hill }\end{array}$ & 2019 & $\begin{array}{l}\text { Parents had, on average, } 73 \\
\text { minutes less sleep at night in the } \\
\text { hospital compared to at home. } \\
\text { Significantly less sleep efficiency } \\
\text { and experienced significantly. }\end{array}$ & \\
\hline $\begin{array}{l}\text { Blomqvist, } \\
\text { Nyqvist, } \\
\text { Rubertsson, and } \\
\text { Funkquist }\end{array}$ & 2017 & $\begin{array}{l}\text { Mothers reported more severe } \\
\text { insomnia than did fathers during } \\
\text { their infants' hospitalization. }\end{array}$ & \\
\hline Franck, et al. & 2014 & $\begin{array}{l}\text { Parents who slept at their } \\
\text { hospitalized child's bedside } \\
\text { experienced more sleep disruption } \\
\text { (waking after sleep onset) and } \\
\text { reported poorer sleep quality and } \\
\text { feeling less rested than parents who } \\
\text { slept at the Ronald McDonald } \\
\text { House. }\end{array}$ & $\begin{array}{l}\text { Further research is needed to understand } \\
\text { sleep for parents who sleep overnight in } \\
\text { a family accommodation room or at the } \\
\text { child's bedside, by either choice or } \\
\text { necessity. }\end{array}$ \\
\hline McCann & 2008 & $\begin{array}{l}\text { Parents experienced sleep } \\
\text { deprivation and poor quality of } \\
\text { sleep, reporting a mean sleep } \\
\text { period of } 4.6 \text { hours }(\mathrm{SD}=2.1)\end{array}$ & $\begin{array}{l}\text { Further research is required to ascertain } \\
\text { whether the WSH sleep scale tool is an } \\
\text { effective way to gain information about } \\
\text { parental sleep in other health care } \\
\text { settings. }\end{array}$ \\
\hline $\begin{array}{l}\text { McLoone, } \\
\text { Wakefield, Yoong, } \\
\text { and Cohn }\end{array}$ & 2013 & $\begin{array}{l}\text { Parents who slept on the pediatric } \\
\text { oncology ward experienced poor } \\
\text { sleep outcomes, including } \\
\text { inadequate duration and frequent } \\
\text { interruptions. }\end{array}$ & $\begin{array}{l}\text { The detrimental effects of sleep } \\
\text { deprivation on parents' ability to cope } \\
\text { during this challenging time require } \\
\text { further investigation. The future research } \\
\text { should also overcome the current study`s } \\
\text { limitation to determine the direction of } \\
\text { the relationship between anxiety and } \\
\text { poor sleep. }\end{array}$ \\
\hline $\begin{array}{l}\text { Meltzer, Davis, and } \\
\text { Mindell }\end{array}$ & 2013 & $\begin{array}{l}\text { Parents reported later bedtimes, } \\
\text { later wake times, and more night } \\
\text { waking when rooming-in. Sleep } \\
\text { was significantly disrupted during } \\
\text { hospitalization. }\end{array}$ & $\begin{array}{l}\text { Further studies should examine sleep } \\
\text { patterns over several consecutive nights, } \\
\text { and also sleep patterns post-discharge. }\end{array}$ \\
\hline $\begin{array}{l}\text { Stickland, Clayton, } \\
\text { Sankey, and Hill }\end{array}$ & 2016 & $\begin{array}{l}\text { Parents reported that they, and to a } \\
\text { lesser extent, their children } \\
\text { experienced reduced sleep quality. }\end{array}$ & \\
\hline Stremler, et al. & 2014 & $\begin{array}{l}\text { More than a quarter of nights met } \\
\text { the criteria for acute sleep } \\
\text { deprivation. There was } \\
\text { considerable variability in the } \\
\text { amount of nocturnal sleep that } \\
\text { individual participants had during } \\
\text { different nights, and sleep was }\end{array}$ & $\begin{array}{l}\text { Future research should focus on } \\
\text { interventions that improve parents' } \\
\text { ability to return to sleep upon awaking } \\
\text { and to maintain regular sleep-wake } \\
\text { schedules. }\end{array}$ \\
\hline
\end{tabular}




\begin{tabular}{|l|l|l|}
\hline & $\begin{array}{l}\text { fragmented with a large portion of } \\
\text { the night spent awake. }\end{array}$ & \\
\hline
\end{tabular}

Table 3. Reported results and recommendations of studies addressing factors affecting parents'

\section{sleep in the hospital.}

\begin{tabular}{|c|c|c|c|}
\hline Author & Year & Results/Conclusions & Future research \\
\hline $\begin{array}{l}\text { Angelhoff, } \\
\text { Edéll-Gustafsson, } \\
\text { and Mörelius }\end{array}$ & 2017 & $\begin{array}{l}\text { Noises made by the staff and medical } \\
\text { treatment were given as reasons that } \\
\text { influenced sleep. }\end{array}$ & \\
\hline $\begin{array}{l}\text { Bevan, Grantham-Hill, } \\
\text { Bowen, Clayton, Grice, } \\
\text { Venditti, Stickland, } \\
\text { and Hill }\end{array}$ & 2019 & $\begin{array}{l}\text { Parents experienced significantly more } \\
\text { sound levels at the hospital than at home. }\end{array}$ & $\begin{array}{l}\text { To study how child and } \\
\text { environmental factors relate to } \\
\text { sleep length and quality. }\end{array}$ \\
\hline $\begin{array}{l}\text { Edéll-Gustafsson, } \\
\text { Angelhoff, Johnsson, } \\
\text { Karlsson, and } \\
\text { Mörelius }\end{array}$ & 2015 & $\begin{array}{l}\text { Anxiety, uncertainty and powerlessness } \\
\text { have a negative influence on sleep. Skin- } \\
\text { to-skin care served as a stress-reducing } \\
\text { factor that improved relaxation and } \\
\text { sleep. The parents also mentioned the } \\
\text { importance of being together. Having a } \\
\text { private place where they could relax and } \\
\text { take care of themselves and their } \\
\text { newborn infant were factors that } \\
\text { improved sleep. }\end{array}$ & \\
\hline $\begin{array}{l}\text { Heinemann, } \\
\text { Hellström-Westas, } \\
\text { and Nyqvist }\end{array}$ & 2013 & $\begin{array}{l}\text { High levels of illumination and noise } \\
\text { rendered it difficult for parents to sleep } \\
\text { and stay overnight with the infant. } \\
\text { Another stress factor was the lack of a } \\
\text { sufficiently private environment } \\
\text { Participants who had other children at } \\
\text { home felt it was difficult for them to stay } \\
\text { overnight with their infant at the NICU. }\end{array}$ & $\begin{array}{l}\text { The variables identified in this } \\
\text { study, together with other } \\
\text { influencing factors can be used } \\
\text { in quantitative research in order } \\
\text { to determine different factors } \\
\text { influencing parents in the } \\
\text { NICU. }\end{array}$ \\
\hline McCann & 2008 & $\begin{array}{l}\text { Having only one child in the hospital } \\
\text { room was the only variable that } \\
\text { significantly influenced the quality or } \\
\text { amount of parental sleep. }\end{array}$ & \\
\hline $\begin{array}{l}\text { McLoone, Wakefield, } \\
\text { Yoong, and Cohn }\end{array}$ & 2013 & $\begin{array}{l}\text { Parents who slept on the ward attributed } \\
\text { poor sleep to feelings of anxiety, } \\
\text { environmental noise, and child-related } \\
\text { factors. }\end{array}$ & $\begin{array}{l}\text { Future research should aim to } \\
\text { determine the direction of the } \\
\text { relationship between anxiety } \\
\text { and poor sleep. This research } \\
\text { should aim to find whether } \\
\text { feelings of anxiety prohibit } \\
\text { sound sleep, or whether poor } \\
\text { sleep exacerbates feelings of } \\
\text { anxiety. }\end{array}$ \\
\hline $\begin{array}{l}\text { Meltzer, Davis, and } \\
\text { Mindell }\end{array}$ & 2013 & $\begin{array}{l}\text { Sleep disturbances due to noises, } \\
\text { worries, pain, vital sign checks, doors } \\
\text { slamming, talking outside the room, or } \\
\text { roommate making noises. These } \\
\text { disturbances were related to latency of } \\
\text { sleep onset, increased night waking's, } \\
\text { and earlier wake times. }\end{array}$ & $\begin{array}{l}\text { Further studies should use } \\
\text { multi-method, multi-reporter } \\
\text { measurement and objective } \\
\text { measurements, door checklists } \\
\text { and light and sound meters to } \\
\text { identify potential sleep } \\
\text { disturbances. }\end{array}$ \\
\hline
\end{tabular}




\begin{tabular}{|l|l|l|l|}
\hline $\begin{array}{l}\text { Nassery and } \\
\text { Landgren }\end{array}$ & 2018 & $\begin{array}{l}\text { Sufficient sleep and rest is described as } \\
\text { vital for parents' functioning. } \\
\text { Factors identified as influencing sleep } \\
\text { and rest in parents were: } \\
\text { Environmental factors e.g., sounds, beds; } \\
\text { Interpersonal factors e.g., relationship } \\
\text { with spouse, relatives, nurses, } \\
\text { physicians, participation in child's care; } \\
\text { Organizational factors e.g., access to } \\
\text { information, food, appropriate } \\
\text { accommodation, bed. }\end{array}$ & \\
\hline $\begin{array}{l}\text { Stickland, Clayton, } \\
\text { Sankey, and Hill }\end{array}$ & 2016 & $\begin{array}{l}\text { Noise and light as well as ward schedules } \\
\text { were identified as key factors disrupting } \\
\text { sleep. }\end{array}$ & \\
\hline $\begin{array}{l}\text { Stremler, Dhukai, } \\
\text { Wong, and } \\
\text { Parshuram }\end{array}$ & 2011 & $\begin{array}{l}\text { Seven themes emerged related to } \\
\text { influences on and strategies to improve } \\
\text { sleep: (1) the child's condition; (2) being } \\
\text { at the bedside or not; (3) difficult } \\
\text { thoughts and feelings; (4) changes to } \\
\text { usual sleep; (5) caring for self and } \\
\text { family; (6) the hospital environment; and } \\
\text { (7) access to sleep locations. }\end{array}$ & $\begin{array}{l}\text { Future research could expand } \\
\text { on our approach to include in- } \\
\text { depth interviews or focus } \\
\text { groups and should include } \\
\text { parents whose children are } \\
\text { staying in general pediatric } \\
\text { units. }\end{array}$ \\
\hline
\end{tabular}

